\title{
KONDISI RUMAH PENDERITA KUSTA DI WILAYAH KERJA PUSKESMAS PEGIRIAN SURABAYA TAHUN 2015
}

Lutfia Sekar Arum, Umi Rahayu, S. B. Ekowarno

\section{ABSTRACT}

Leprosy is contagious diseaes that cannot be solved optimally in Surabaya, this compounded by still many densely population area that is uninhabitable. Housing and environments conditions that do not meet health requirements are risk factors for leprosy transmission source. In the work area of Pegirian Community Health Center of Surabaya in 2014 they are 17 Lepers.This research aims to describe house physical condition of lepers.

The type of research is descriptive with observational approach. The data collection is done by measurement and observation, the amount taken of samples is 17 houses lepers. The collected data is analysis descriptively with descriptions explanation based on the Decree of Ministry of Health of republic of Indonesia No. 829 Year 1999 regarding healthy houserequirements.

The result showed that ventilation of studied lepers' house is ineligible $94.12 \%$. The temperature of the houses that does not qualify is $41.17 \%$. Humidity which is not qualified is $47.05 \% .100 \%$ natural lighting of lepers' house is ineligible. Lepers' house which is densely populated is $94.25 \%$, the condition of floor does not qualify is $29.41 \%$.

The suggestion is open a window, then sunlight can get into house, and install the glass tile Always keep the house clean.

\section{Keywords : Lepers, House physical condition.}

\section{PENDAHULUAN}

Kusta adalah penyakit infeksi kronis yang di sebabkan kuman mycobacterium Leprae yang dapat menular melalui percikan/ droplet, pernafasan dan kontak kulit.

Kondisi fisik rumah yang tidak memenuhi syarat kesehatan akan menjadi media penularan penyakit terutama penyakit kusta. untuk memenuhi kebutuhan fisiologis rumah perlu dilakukan penyehatan kondisi fisik rumah yang sesuai dengan peraturan Kepmenkes no.289 th 1999.

Di surabaya tercatat 131 penderita kusta baru pada tahun 2013. Berdasarkan data yang diperoleh dari Dinas Kesehatan Kota Surabaya tahun 2013 ada dua Puskesmas yang menangani kasus kusta tertinggi yaitu Puskesmas Perak Timur dengan jumlah kasus 12 penderita kusta dan Puskesmas Pegirian dengan jumlah kasus 9 penderita kusta. Sedangkan tahun 2014 puskesmas yang menangani kasus kusta tertinggi yaitu Puskesmas Pegirian Kecamatan Semampir, dengan jumlah kasus 20 penderita kusta. Sedangkan puskesmas perak timur di tahun 2014 ada 16 penderita kusta.

Ini menunjukan bahwa penderita kusta dari tahun 2013 hingga tahun 2014 mengalami peningkatan. Dari survei awal yang telah dilakukan diperoleh informasi bahwa kondisi rumah di wilayah kerja Puskesmas Pegirian berada di lingkungan rumah yang padat penghuni serta kebiasan warga jarang membuka jendela sehingga memungkinkan kondisi rumah yang baik untuk berkembangbiaknya bakteri Mycobacterium Leprae.

Tujuan dari penelitian ini yaitu menggambarkan Kondisi Fisik Rumah Penderita Kusta di Wilayah Kerja Puskesmas Pegirian Surabaya Tahun 2015.

\section{METODE PENILAIAN}

Jenis penelitian ini adalah deskriptif dengan pendekatan observasional. Lokasi penelitian dilakukan di wilayah kerja Puskesmas Pegirian Surabaya, mulai dari bulan aprli sampai dengan juli dan sampel dalam penelitian yaitu rumah penderita kusta di wilayah kerja Puskesmas Pegirian Surabaya sebanyak 17 rumah.

Pengumpulan data yang di peroleh dengan melakukan observasi dan pengukuran kondisi fisik rumah penderita kusta yaitu luas ventilasi, suhu, kelembaban, pencahayaan, kepadatan hunian, dan kondisi lantai rumah. Data yang terkumpul selanjutnya dianalisa secara deskriptif dengan uraian pembahasan berdasarkan Keputusan Menteri Kesehatan RI No. 829 tahun 1999 tentang persyaratan rumah sehat. 


\section{hASIL PENELITIAN DAN PEMBAHASAN}

Berdasarkan tabel 1, didapatkan hasil bahwa sebagian besar luas ventilasi rumah penderita kusta tidak memenuhi syarat sebesar $94,12 \%$ yaitu 16 rumah, dan hanya ada 1 rumah yang memenuhi syarat dengan prosentase $5,88 \%$. sebagian besar rumah penderita memiliki jendela yang kecil bahkan ada yang tidak memiliki jendela.

Hal tersebut menjadikan terhalangnya pertukaran udara sehingga bakteri patogen tidak dapat keluar dan ikut terhisap bersama udara pernafasan terutama Mycobacterium leprae. Maka penting bagi setiap rumah memiliki ventilasi yang memenuhi syarat dan mengfungsikan ventilasi sebagaimana fungsinya dengan membuka jendela pada pagi hari, sehingga cahaya matahari dapat masuk kedalam rumah dan sebagai keluar masuknya udara dengan cara membuka ventilasi /membuat lubang hawa.

Tabel 1.

Luas ventilasi rumah penderita kustadi wilayah kerja puskesmas Pegirian Surabaya tahun 2015

\begin{tabular}{|c|l|c|c|}
\hline \multirow{2}{*}{ No } & \multicolumn{2}{|c|}{ ventilasi } & \multicolumn{2}{|c|}{ Jumlah } \\
\cline { 3 - 4 } & & 1 & Frekuensi \\
\hline 1 & Memenuhi Syarat & 16 & 5,88 \\
\hline 2 & Tidak Memenuhi Syarat & $\mathbf{1 7}$ & 11,76 \\
\hline \multicolumn{2}{r}{ Jumlah } & & $\mathbf{1 0 0}$ \\
\hline
\end{tabular}

Sumber data primer

Berdasarkan tabel 2, didapatkan hasil bahwa sebagian besar suhu rumah penderita kusta memenuhi syarat yaitu 10 rumah dengan prosentase sebesar 58,82\%. Sedangkan suhu rumah yang Tidak memenuhi syarat yaitu 7 rumah dengan prosentase sebesar $41,17 \%$, karena suhunya lebih dari $30^{\circ} \mathrm{C}$. Kondisi suhu ruang yang memenuhi syarat menjadi tempat yang baik untuk Mycobacterium Leprae berkembang biak, hal ini terbukti karena Mycobacterium Leprae dapat hidup dengan baik pada suhu $27-30^{\circ} \mathrm{C}$ menurut Depkes RI, 2012. Mycobacterium Leprae dapat hidup baik pada suhu yang memenuhi syarat, oleh karena itu komponen rumah lainya harus dipenuhi yaitu, ventilasi, kelembaban, pencahayaan, kepadatan hunian yang memenuhi syarat. Hal tersebut dilakukan agar mencegah Mycobacterium Leprae untuk berkembang biak.

Tabel 2.

Suhu rumah penderita kusta di wilayah kerja Puskesmas Pegirian Surabaya tahun 2015

\begin{tabular}{|c|l|c|c|}
\hline \multirow{2}{*}{ No } & \multicolumn{2}{|c|}{ Suhu } & \multicolumn{2}{c|}{ Jumlah } \\
\cline { 3 - 4 } & & Frekuensi & \% \\
\hline 1 & Memenuhi Syarat & 10 & 58,82 \\
\hline 2 & Tidak Memenuhi Syarat & 7 & 41,17 \\
\hline \multicolumn{2}{r}{ Jumlah } & $\mathbf{1 7}$ & $\mathbf{1 0 0}$ \\
\hline
\end{tabular}

Sumber data primer

Berdasarkan tabel 3, didapatkan hasil bahwa sebagian besar kelembaban rumah penderita kusta memenuhi syarat yaitu 9 rumah dengan prosentase sebesar 52,94\%. Sedangkan yang tidak memenuhi syarat yaitu 8 dengan prosentase 47,05\%, yaitu kelembabannya lebih dari $70 \%$ dikarenakan tidak adanya sirkulasi udara dan pencahayaan yang kurang di dalam rumah penderita. Kelembaban yang disarankan khusus untuk ruangan rumah menurut Kepmenkes RI No. 829 tahun 1999, adalah berkisar antara 40-70 \%. Orang sehat yang serumah dengan penderita kusta akan mudah tertular dengan kondisi rumah yang lembab. Kondisi rumah yang lembab menjadi media yang baik untuk mikroorganisme dan mempercepat penularan Mycobacterium Leprae melalui kontak kulit maupun pernafasan. Sehingga adanya lubang hawa atau ventilasi akan mengurangi kelembaban di dalam rumah.

kelembaban yang tinggi dapat menyebabkan membran mukosa hidung menjadi kering sehingga kurang efektif dalam menghadang mikroorganisme. Kelembaban untuk M.Leprae dapat hidup 
dalam sekret hidung yang dikeringkan pada temperatur kamar $36,7^{\circ} \mathrm{C}$ dengan kelembaban $77,6 \%$. M.leprae dapat bertahan hidup 7-9 hari pada kelembaban 70,9\%. Sedangkan temperatur kamar dibuktikan dapat bertahan hidup sampai 46 hari.

Tabel 3.

Kelembaban rumah penderita kusta di wilayah kerja Puskesmas Pegirian Surabaya tahun 2015

\begin{tabular}{|c|l|c|c|}
\hline \multirow{2}{*}{ No } & Kelembaban & \multicolumn{2}{|c|}{ Jumlah } \\
\cline { 3 - 4 } & & Frekuensi & \% \\
\hline 1 & Memenuhi Syarat & 9 & 52,94 \\
\hline 2 & Tidak Memenuhi Syarat & 8 & 47,05 \\
\hline \multicolumn{2}{r}{ Jumlah } & $\mathbf{1 7}$ & $\mathbf{1 0 0}$ \\
\hline
\end{tabular}

Sumber data primer

Berdasarkan tabel 4, didapatkan hasil bahwa pencahayaan yang tidak memenuhi syarat sebesar $100 \%$. Karena kondisi rumah semua penderita kusta gelap yaitu kurang dari 60 lux. Berdasarkan observasi semua rumah penderita kusta tidak memungkinkan cahaya matahari masuk kedalam rumah, tidak adanya ventilasi serta ada juga ventilasi yang tidak difungsikan. rumah penderita memiliki jendela kecil dan jarang dibuka bahkan ada yang tidak memiliki jendela. Hal ini akan menguntungkan bagi Mycobakterium Leprae untuk berkembang biak, cahaya matahari berfungsi untuk membunuh bakteri-bakteri patogen di dalam rumah. Cahaya matahari mempunyai sifat membunuh bakteri, terutama Mycobacterium leprae. Sehingga perlu adanya ventilasi dan jendela di setiap ruang terutama kamar tidur, kebiasaan membuka jendela dan tirai /korden setiap pagi serta dapat juga memasang genteng kaca agar matahari dapat masuk kedalam rumah.

Tabel 4.

Pencahayaan rumah penderita kusta di wilayah kerja Puskesmas Pegirian Surabaya tahun 2015

\begin{tabular}{|c|l|c|c|}
\hline \multirow{2}{*}{ No } & \multirow{2}{*}{ Pencahayaan } & \multicolumn{2}{|c|}{ Jumlah } \\
\cline { 3 - 4 } & & Frekuensi & \% \\
\hline 1 & Memenuhi Syarat & 17 & 100 \\
\hline 2 & Tidak Memenuhi Syarat. & $\mathbf{1 7}$ & $\mathbf{1 0 0}$ \\
\hline & Jumlah & \multicolumn{2}{c|}{} \\
\hline
\end{tabular}

Sumber data primer

Berdasarkan tabel 5, didapatkan hasil bahwa 16 rumah dengan prosentase sebesar $94,12 \%$, Karena jumlah penghuni melebihi dari $8 \mathrm{~m}^{2} / 2$ orang. Sedangkan yang memenuhi syarat yaitu 1 rumah dengan prosentase sebesar $5,88 \%$. Rumah padat penghuni menyebabkan resiko penularan penyakit kusta lebih intensif karena penularan Mycobacterium Leprae melalui saluran pernafasan dan kontak kulit. Semakin banyaknya orang yang menepati suatu rumah maka memudahkan penularan Mycobacteroium Leprae yang menyebar melalui udara.

Tabel 5.

Kepadatan hunian rumah penderita kusta di wilayah kerja Puskesmas Pegirian Surabaya tahun 2015

\begin{tabular}{|c|c|c|c|}
\hline \multirow{2}{*}{ No } & \multirow{2}{*}{ Kepadatan hunian } & \multicolumn{2}{|c|}{ Jumlah } \\
\cline { 3 - 4 } & & 1 & Frekuensi \\
\hline 1 & Memenuhi Syarat & 16 & 5,88 \\
\hline 2 & Tidak Memenuhi Syarat & $\mathbf{1 7}$ & 94,12 \\
\hline \multicolumn{2}{r}{ Jumlah } & $\mathbf{1 0 0}$ \\
\hline
\end{tabular}

Sumber data primer 
Berdasarkan tabel 6, didapatkan hasil bahwa sebagian besar lantai rumah semua penderita memenuhi syarat yaitu 12 rumah dengan prosentase sebesar $70,58 \%$ yaitu kedap air dan mudah dibersihkan. Sedangkan lantai rumah yang tidak memenuhi syarat yaitu 5 rumah dengan prosentase sebesar $29,41 \%$ karena lantai tidak kedap air (plesteran) dan kondisi lantai rumah terlihat berdebu. Jenis lantai dengan plester yang retak atau berdebu berpotensi terhadap keberadaan bakteri. Menurut Depkes RI (2006), Mycobacterium Leprae mampu hidup di luar tubuh manusia dan dapat ditemukan pada tanah atau debu di sekitar lingkungan rumah penderita. di luar tubuh manusia (dalam kondisi tropis) kuman kusta bertahan sampai 9 hari.

Tabel 6.

Lantai rumah penderita kusta di wilayah kerja Puskesmas Pegirian surabayaTahun 2015

\begin{tabular}{|c|l|c|c|}
\hline \multirow{2}{*}{ No } & \multicolumn{2}{|c|}{ Lantai } & \multicolumn{2}{|c|}{ Jumlah } \\
\cline { 3 - 4 } & & Frekuensi & \% \\
\hline 1 & Memenuhi Syarat & 12 & 70,58 \\
\hline 2 & Tidak Memenuhi Syarat & 5 & 29,41 \\
\hline \multicolumn{2}{r|}{ Jumlah } & $\mathbf{1 7}$ & $\mathbf{1 0 0}$ \\
\hline
\end{tabular}

Sumber data primer

\section{KESIMPULAN}

Kondisi ventilasi udara menunjukan bahwa rumah penderita kusta di wilayah kerja Puskesmas Pegirian Surabaya tidak memenuhi syarat sebesar $94,12 \%$. Suhu rumah yang tidak memenuhi syarat sebesar $41,17 \%$. Kelembaban rumah penderita kusta tidak memenuhi syarat sebesar $47,05 \%$. Pencahayaan rumah penderita kusta di wilayah kerja Puskesmas Pegirian Surabaya menunjukkan bahwa semua rumah penderita kusta tidak memenuhi syarat. Rumah penderita kusta padat penghuni sebesar $94,12 \%$. Lantai rumah penderita kusta tidak memenuhi syarat sebesar $29,41 \%$ di wilayah kerja Puskesmas Pegirian Surabaya.

\section{SARAN}

Saran yang dapat diajukan yaituselalu membuka jendela agar cahaya matahari dapat masuk kedalam rumah, dapat juga memasang genteng kaca. Serta menjaga kondisi rumah agar selalu bersih. Dinas kesehatan setempat memberikan penyuluhan kepada masyarakat mengenai penularan kusta di lingkungan rumah sehingga dapat mencegah penularan basil Leprae di rumah, Serta untuk meningkatkan upaya kesehatan khususnya kesehatan pemukiman.

\section{DAFTAR PUSTAKA}

Candra, Budiman. 2012. Pengantar kesehatan lingkungan. Jakarta. Buku kedokteran, EGC: 63-68.

Departemen Kesehatan RI.2012 .Pedoman Nasional Program Pengendalian Penyakit Kusta.Jakarta: Dirjen P2PL.
Dinkes Surabaya, 2013. Profil Kesehatan Surabaya tahun 2013 tentang penyakit kusta. Surabaya: Dinas Kesehatan Surabaya.

Keputusan Menteri Kesehatan Republik Indonesia No. 829/Menkes/SK/VII/1999 tentang Persyaratan Kesehatan Perumahan. Jakarta: Departemen Kesehatan R.I.

Mandal,dkk.2011. Lecture Notes on Infectious Dieses.Jakarta: Erlangga.Edisi Enam:130-131.

Mubarok, Chayatin.2010.I/mu Kesehatan Masyarakat:Teori dan Aplikasi. Jakarta: Salemba Medika:281-283.

Notoatmodjo, Soekidjo. 2011. Kesehatan Masyarakat:IImu dan Seni. Jakarta. Rineka Cipta:37-38,172-175.

Notoatmodjo, Soekidjo. 2010. Metodologi penelitian Kesehatan. Jakarta. Rineka Cipta:35-36,

Riviwanto,Muchsin,dkk.2011.Penyehatan Pemukiman(Seri Kesehatan Lingkungan). Editor: Kasjono.Yogyakarta.GosyenPublising: 22-60.

Soedarto, 2011. Penyakit-Penyakit Infeksi di Indonesia.Jakarta: Widiya Medika:9495.

Suyono, Budiman. 2010. I/mu Kesehatan Masyarakat Dalam Konteks Kesehatan Lingkungan.Jakarta: EGC: 84-86.

Widoyono, 2011. Penyakit tropis, Epidemiologi, penularan, pencegahan dan pemberantasan. Edisi 2. Jakarta: EGC: 63-68.

Widoyoko, E.p, 2014. Teknik Penyusunan Instrumen Penelitian. Yogyakarta, Pustaka Belajar. 